\title{
Swiss humanitarian aid during the Spanish Civil War: The journey of Anna Siemsen and Regina Kägi-Fuchsmann*
}

\author{
Luís Manuel Calvo Salgado \\ Kunsthistorisches Institut, University of Zurich \\ e-mail: lcalvo@khist.uzh.ch \\ ORCID iD: https://orcid.org/0000-0002-2100-9544
}

Submitted: 18 May 2018. Accepted: 24 March 2019

\begin{abstract}
Anna Siemsen's and Regina Kägi-Fuchsmann's journey to Spain in May 1937 resulted in two accounts regarding their experiences and views of Swiss humanitarian aid in the Civil War. The comparison between these two narratives makes it possible to study the role and the expression of fear, sadness and indignation at the bombing and the forced displacement of the civil population during the war. They are shared emotions yet expressed by each one in different ways depending on the function of their ideas and their perceptions. The empathy with the displaced people, especially with the children evacuated from Madrid to Valencia and Catalonia, is the main motivation of the participants in the Swiss humanitarian aid to Republican Spain, which raises some moral dilemmas. This empathy is furthermore characterized by a strong sympathy for the civil, social and democratic values represented by the Spanish Republic. Anna Siemsen's and Regina Kägi-Fuchsmann's religious and ideological beliefs, however, establish the limits of their empathy.
\end{abstract}

KEYWORDS: Spanish Civil War; History of emotions; Humanitarian aid; Swiss Aid empathy; Volunteers.

Citation / Cómo citar este artículo: Calvo Salgado, Luís Manuel (2019) "Swiss humanitarian aid during the Spanish Civil War: The journey of Anna Siemsen and Regina Kägi-Fuchsmann". Culture \& History Digital Journal, 8 (2): e018. https:// doi.org/10.3989/chdj.2019.018

RESUMEN: Ayuda humanitaria suiza durante la Guerra Civil española: El viaje de Anna Siemsen y Regina KägiFuchsmann.- El viaje de Anna Siemsen y de Regina Kägi-Fuchsmann a España en mayo de 1937 se plasmó en dos narraciones sobre sus experiencias y sus visiones de la ayuda humanitaria durante la Guerra Civil. La comparación entre estas dos narraciones permite estudiar el papel y la expresión del miedo, la tristeza o la indignación ante los bombardeos y los desplazamientos forzados de la población civil durante la guerra. Son emociones compartidas pero expresadas en cada caso de manera diferente dependiendo de sus ideas y de sus percepciones. La empatía con los desplazados, especialmente con los niños de Madrid en Valencia y Cataluña, es la principal motivación de los participantes en la ayuda humanitaria suiza a la España republicana, lo que les plantea diversos dilemas. Esta empatía está además caracterizada por una fuerte simpatía por los valores civiles, sociales y democráticos que representaba la República española. Las creencias religiosas y la ideología de Anna Siemsen y Regina Kägi-Fuchsmann marcan, sin embargo, los límites de su empatía.

PALABRAS CLAVE: Guerra Civil Española; Historia de las emociones; Ayuda humanitaria; Ayuda Suiza; Empatía; Voluntarias.

Copyright: (C) 2019 CSIC. This is an open-access article distributed under the terms of the Creative Commons Attribution 4.0 International (CC BY 4.0) License. 


\section{INTRODUCTION}

Anna Siemsen and Regina Kägi-Fuchsmann travelled to Spain in May 1937 on behalf of a Swiss nongovernmental organization, the Schweizerisches Arbeiterhilfswerk (Swiss Labour Aid) to coordinate humanitarian aid to the civilian population living in the Republican zone. The accounts they made of that journey resulted in two parallel narratives which allow us to study and compare, from a transnational perspective, the role and the interpretation of emotions of two different people during humanitarian relief efforts. The two women experienced the same events, but they did not experience them in quite the same way. Their perception differs and the way they express their emotions in the texts is profoundly individual. The fact that they travelled together allows us to compare specific points of their reports in order to understand how they are told and what has gone unmentioned. In the study of the history of emotions it is crucial to consider the variety of individual accounts, as well as to understand the emotional practices within society itself. Above all, one should not fall into the trap of adopting a relativistic perspective which would stand in the way of a political criticism of the emotional practices of the society under study - in this case European society in the 1930s. Moreover, according to the ideas expounded by William M. Reddy, emotions are to be understood as cognitive areas, as opposed to biologically pre-programmed responses (Reddy, 2010).

Comparing the two accounts has the advantage of underscoring specific contrasts and giving us a better understanding of how emotions are individually expressed. It is not a question of summarizing the emotional experience of the volunteers who providing humanitarian aid during the Civil War, but of focusing on the similarities and the differences in the women's expression of their experiences, as well as recognizing how memory filters each individual recollection. The two memoirs allow us to observe how the emotional regimes of the volunteers' native countries (the National Socialist dictatorship in Germany in Anna Siemsen's case, and the Swiss democracy in Regina Kägi-Fuchsmann's case) influenced their perceptions of the humanitarian effort during the Civil War and of the Spanish Republic. Their previous experiences, their academic studies and their social democratic leanings (both in Germany and Switzerland) contribute to explaining their reactions and the nature of the emotions they report on. The curiosity they display during their journey, and the stylistic skills shown in their accounts can also be read through an emotional lens. Their way of observing the environment and narrating it - for instance, by adding or omitting details, by describing their interactions with the local population or by choosing to include or disregard background information - make their accounts different from each other but also, in sense, complementary.

\section{BIOGRAPHICAL SIMILARITIES BETWEEN THE AUTHORS}

Both women started to consider the idea of becoming involved with the humanitarian relief effort because of their own emotional turmoil. Anna Siemsen's exile to Switzerland in 1933 (Siemsen, 1951: 59-72) ${ }^{1}$ had a strong emotional impact upon her. For Regina KägiFuchsmann the emotional suffering was the result of childhood experiences; furthermore, she also had two children, one of them with a serious psychical disorder that could not be treated adequately (Kägi-Fuchsmann, 1968: 67-81). Both Siemsen and Kägi-Fuchsmann found an emotional haven in SAH, a humanitarian organization, which was linked to the Swiss labour movement and supported by the unions and by the Swiss Social Democratic Party. At the same time, however, this emotional haven was to become the source of further emotional suffering. It was within the $\mathrm{SAH}$ framework that Anna Siemsen and Regina Kägi-Fuchsmann planned their journey to Spain, and what they witnessed there, notably the cruelty against the civilian population, led to much distress and turmoil. ${ }^{2}$ Furthermore, SAH can be considered an emotional community in Barbara Rosenwein's sense of the word; that is to say, a group with a system of feelings and a shared code, which implies observing certain policies and recognizing the existence of a series of common emotional values (Rosenwein, 2006, 2002: 821-845).

Because of their academic background and their experiences, both Anna Siemsen and Regina Kägi-Fuchsmann had developed a particular aptitude required by certain tasks connected to humanitarian aid. Both had received training in education and were interested in pedagogy; this helped them to establish a reflexive emotional relation with the people who were benefiting from their humanitarian projects. Anna Siemsen (1882-1951) was the daughter of a Protestant minister (Siemsen, 1951: 9-19) and graduated as a teacher in Münster in 1901. She first worked as a private teacher and then, from 1905 to 1911, she studied German, Philosophy and Latin in Munich, Münster and Bonn (Bauer, 2012: 32-39). In 1909, she completed her Ph.D. and in 1910, she passed the state examination to teach in secondary education. She carried out pedagogic training in 1912 and underwent an additional examination in Evangelical Religion at Göttingen University. Her studies, therefore, made her supremely qualified to discuss education and pedagogical topics; a particular interest of hers was the role of literature and art in education. Her writings on pedagogy and literature focus on what is known as the "empathic concept of reason" ("empathischer Vernunftbegriff") (Borst, 2000: 6990). This concept is also important to understand her attitude during her time as volunteer in the years of the Spanish Civil War. Her political commitment to the Social Democracy ever since the Great War and her vision of education as an engine of social change explain her interest in the educational projects of the Second Spanish Republic. 
Anna Siemsen had administrative and political positions of a certain relevance under the Weimar Republic and she was affiliated to different social-democratic parties throughout her life (Bauer, 2012: 78-80). From 1920 to 1921 , she was appointed delegate for a vocational school in Düsseldorf and from 1921 to 1923 she had a position of responsibility in secondary education in Berlin, where she also joined a spirited association of teachers campaigning for a school reform in Germany. In 1923, she became a teacher at the University Friedrich Schiller of Jena, but in 1933, the government of Thuringia, under the influence of National Socialist Fritz Sauckel, withdrew her teaching qualification because she had signed a letter in support of mathematician and publicist Emil Julius Gumbel, who was also purged. During that period, she was one of the few university teachers left in Germany (there were 44 in 1928) (Bauer, 2012: 94-100).

After Hitler's appointment to Reichskanzler on January 30th, 1933, Anna Siemsen began to feel increasingly threatened. On February 26th, 1933, one day before the Reichstag fire, she was notified of the suicide of two of her friends, who were also university teachers (Bauer, 2012: 101-103). It was then that she decided to go into exile with her brother August and her sister-in-law. The three of them moved to Switzerland, a country that Siemsen knew well and where she had contacts with social democratic academics and affiliates of Protestant-oriented socialism like Leonhard Ragaz. In Switzerland, she became actively engaged into the local labour movement while also taking part to political and union activities in support of European federalism. It is with an anecdote that her brother August describes the health problems his sister started to suffer from soon after their arrival in Switzerland, particularly a severe loss of hearing: he remembers how she could not hear him as he was calling her repeatedly from the door (Siemsen, 1951:73-74). To be able to obtain residence and work permits, in 1934 she married Walter Vollenweider (1903-1971), the secretary of the Swiss Labour Youth, who was gay. Because of her brother's difficulties with the Swiss authorities, which eventually forced him to move to Argentina, she became aware of the problems experienced by German exiles living in Switzerland. This led her to voice explicit criticism of the migratory and external affairs policies of her host country (Siemsen, 1951:7476). Her husband was a member of SAH's management team, which became, as mentioned above, her emotional refuge and community. The organization was presided over by Regina Kägi-Fuchsmann. Its activity focused on educational projects for children and SAH's youth, but it also participated in events organized by the Social Democratic teachers' organisation, by the Swiss Socialist party, and by the Swiss branch of the 'Union des instituteurs allemands émigrés'(Bauer, 2012: 107-108). Starting in 1938, she was in charge of the magazine 'Die Frau im Leben und Arbeit' ('The woman in life and at work'), a monthly publication of the Swiss Social Democratic women's association (Siemsen, 1951:81-83).

The experience of the purges in Germany, her brother's departure to Argentina and her increasing awareness that she'd been exiled from her country all contributed to a strong sense of loss. During her stay in Switzerland, she had been forced to emotionally rebuild her whole life and her personal and professional projects. Despite the worsening of her deafness and the problems with the authorities, she managed to keep moving forward. Her main reaction to a difficult situation was a growing commitment to the political and intellectual views of social democracy, to education and to humanitarian aid. Her activism and her writing took up most of her time. She was working through her exile in a dynamic and flexible way, both in the emotional and the professional sphere. The forced relocation of her brother and her sister-in-law to Argentina did not prevent her from maintaining a strong bond with them. On the contrary: they exchanged letters frequently and, in order to protect him, she published her brother's book under her own name. This was 'The German empire', a book that was later to be translated into Spanish in Argentina under the title 'El imperio germano. Peligro de Europa' ('The German empire. Europe's danger'). Anna Siemsen was in complete agreement with its content, a fierce critique of German nationalism, Germany's militaristic regime and the National Socialist ideology (Siemsen, 1939, 1981). The publication of the book coloured the intellectual and political experiences of her exile with a strong transnational character. After the Second World War, Siemsen returned to Germany but she could not regain her permanent position as a university teacher; she was assigned courses only sporadically. From her return in 1946 to her death in 1951, she was a member of the SPD; within the party, she organized academic training and kept working within the Socialist Movement towards European unification and the United States of Europe (Bauer, 2012: 116-129; Siemsen, 1951:87-95).

Regina Kägi-Fuchsmann was born in 1889 in Zurich and grew up with her six brothers in a family with limited resources. Her parents were Lithuanian Jews who had fled to France so her father could avoid compulsory military service. Her parents had tried to remain in Paris, but they had not been able to find work. They had moved to Zurich in 1887 and opened a shop specialized in food products from the Baltic (Kägi-Fuchsmann, 1968: 13). In her autobiography, Regina Kägi-Fuchsmann describes the hardships of her family life as the root of her passion for reading and her interest in education. Her father suffered from alcoholism, and her mother was therefore forced to manage both the shop and their household, thus making it difficult to establish a satisfactory emotional bond with her children (Kägi-Fuchsmann, 1968: 15-17). Regina Kägi-Fuchsmann's interest in politics emerged early on due to the contact with her Russian relatives visiting Zurich: they told her about their revolutionary ideas, which she considered too extreme. This led her to an early affiliation to the Swiss Social Democratic Party. Furthermore, she strongly identified with the teetotalism movement supported by the Protestant clergy, where she met many of her friends (Kägi-Fuchsmann, 1968: 21-23).

Her desire to work with children and the influence of Protestant minister Leonhard Ragaz, who believed in ed- 
ucation as an instrument of social change, were the reasons behind her decision to study primary education (Kägi-Fuchsmann, 1968: 35-37). During her studies to become a teacher at the University of Zurich, she met the man who was later to become her husband: Paul Kägi, who was also a member of the teetotalism movement (Kägi-Fuchsmann, 1968: 52-53). Once she finished her degree, she first worked as a private teacher; next, she moved to Schaffhausen where her husband taught Latin for a few months. There she learned the ropes in a workers' organization and later, in the 1920s, she joined the Schaffhauser Frauenzentrale (an association in favour of women's rights), first as a secretary and then as its president (Kägi-Fuchsmann, 1968: 85-93). Swiss legislation at the time, which she vehemently opposed, prevented her from seeking a position in the public Education sector because she was married; this despite the fact that she was qualified to work there (Kägi-Fuchsmann, 1968: 87).

In her autobiography, she describes World War I as a crucial time for her vital, emotional and intellectual development. From the very beginning of the war, Regina Kägi-Fuchsmann and her friends were hounded by pessimism, because their pacifist ideals were being threatened by the international situation. The aftermath of the war, and the defeat and repression of the Swiss general strike (which took place between November 11th and 14th, 1918) caused her and her loved ones to experience "bereavement", which prevented them from feeling "joy in their hearts". She felt the need "to do something to create a better world". In the personal sphere, she considered the end of war as the "end of youth and the beginning of maturity". This led her to believe that she could find happiness again only by working for the common good (KägiFuchsmann, 1968: 65-17). The dramatic experience she experienced because of her son Peter (1919-1942), who was affected by mental illness and whom Kägi-Fuchsmann and her husband had to hospitalize until his death, tainted her private life with sadness for many years, but also motivated her to help other children in vulnerable situations (Kägi-Fuchsmann, 1968: 67-81).

The 1930s were a crucial time for Kägi-Fuchsmann as the period which prompted the shift towards humanitarian aid. After the 1929 crisis, there were mass redundancies in the textile and watch industry. The Social Democratic Women responded by providing support for vulnerable families, with a particular focus on minors and unemployed workers. In 1932, Regina Kägi-Fuchsmann's husband was appointed officer for the Secretariat of Youth, and the couple returned to live in Zurich. Her first role there was the organization of a professional association for travelling saleswomen with a view to improving their employment opportunities (Weil, 2010: 42). In those years, Switzerland was also taking in German and Austrian social democrats who had left their countries for political reasons. Regina Kägi-Fuchsmann became involved in this cause by offering increasing help to this new wave of refugees. This is why, in 1933, she was appointed as the first director of the recently created Secretariat of the Swiss Children Relief (Schweizerische Kinderhilfe), later called Workers' Children Relief (Arbeiterkinderhilfe) which was founded by the Swiss Social Democratic Party, trades unions, the Socialist Women group and the Friends of Nature (Weil, 2010: 43-45). In 1936, she became the director of Schweizerisches Arbeiterhilfswerk (SAH, Swiss Labour Assistance), the most important non-governmental organization and humanitarian aid close to socialist trade unions. All of these organizations were characterized by a culture of empathy towards the refugees from the neighbouring countries, a constant feature of the Swiss labour movement in the ' $30 \mathrm{~s}^{3}$ With the beginning of the Civil War, that same culture of empathy would favour the emergence of actions of solidarity and humanitarian aid in support of the Republic. ${ }^{4}$ During that same period, Regina Kägi-Fuchsmann actively participated in the activities of the women's group of the Social Democratic Party in Zurich until her resignation as SAH director for health reasons in 1951 (Kägi-Fuchsmann, 1968: 121). Since then, and until her death in 1972, she remained committed to social work and shared what she had learned in the field through numerous conferences (Weil, 2010: 42). Furthermore, she played an important role in favour of the humanitarian relief effort and world peace, especially as vice-president of the non-European aid organization Schweizerisches Hilfswerk für aussereuropäische Gebiete (SHAG), later called Helvetas. This position allowed her to travel to many countries in order to check the development of aid projects such as the one established to support agriculture in Nepal (Kägi-Fuchsmann, 1968: 304-307). In 1961, she was awarded a Doctor Honoris Causa degree by the University of Zurich. ${ }^{5}$

\section{THE JOURNEY TO SPAIN}

Because of the Swiss humanitarian aid plan, at the beginning of 1937 curiosity about what was happening in Spain started to increase; this is mentioned by both authors in their texts. In Anna Siemsen's case, a travel diary first published in 1938 and re-edited in 1947, which was intended to encourage a sense of solidarity with the civilians of the Spanish Republic. In Regina Kägi-Fuchsmann's case, the chapter of her autobiography, published in 1968, in which she speaks about her journey to Spain. This offers a later reflection on the events through a twofold historical perspective: on the one hand, the discussions and debates the war sparked in Switzerland and on the other, the country's active role in Spain (i.e., the high number of Swiss volunteers who fought for the Republic, and the humanitarian aid the country provided). ${ }^{6}$

Both women developed a twofold vision of Republican Spain as a country which was both engaged in a fight against "fascism" while also in need of humanitarian aid and victimized by a Total War they considered mechanized and inhuman. For Anna Siemsen, therefore, the Spanish Republic is on the one hand a progressive democratic model, looking towards the future and ready to defend itself against a military uprising despite the lack of international help and a civilian population martyred by the insurgent air raids. On the other hand, however, for 
Regina Kägi-Fuchsmann the Republic does embodies those values while also foreshadowing the danger of leftwing totalitarianism because of URSS's influence in the conflict. As a result, she justifies the provision of humanitarian aid but is also critical of the republican repression in her area and underscores the organizational problems of some of the republican institutions in charge of helping the displaced.

I will now discuss the two authors' emotions and how they are expressed in the texts they wrote about Swiss humanitarian aid with a focus on the following subjects: the relation between their reactions and their emotions (somewhat contradictory when talking about the air raids); the exodus of civilians from the bombarded cities; and the situation of the children living in the republican area. I will explain the similarities and the differences found in the texts I studied against the backdrop of other texts of that period, the propaganda of the republican institutions and the solidarity campaigns in Switzerland.

\section{Air raids and death: fear, grief and indignation}

Regina Kägi-Fuchsmann describes in her autobiography how Anna Siemsen cried for hours when she read in the press about the bombing of Guernica on April 26th, 1937. She wondered: "Is it possible for my compatriots she was German - to be such dehumanized beasts?" (Kägi-Fuchsmann, 1968: 154). For Regina Kägi-Fuchsmann, her journey with Anna Siemsen was "an exciting adventure". Before her departure, she had many questions: "What happens to a country going through a war? What can we do with our own weak power? Would it be possible to move the children to Switzerland? What kind of help will be necessary?" In December 1936, the petition launched by SAH and other organizations demanding that children from the bombarded areas be taken in for a minimum of three months was denied by the Swiss authorities which feared that the children would end up remaining in the country for a longer period of time by using public funds. In late January 1937, a similar petition was also turned down. It became clear that SAH could not succeed in securing support for the Spanish children without the help of a larger, more neutral coalition, both in political and religious terms (Weil, 2010:45-48). Initially, the possibility of evacuating children to Switzerland was raised, but the trips made by Anna Siemsen and Regina KägiFuchsmann contributed, among other things, to a better understanding of the position of the republican government in this matter; position which, at that time, was opposed to evacuation to foreign countries. The original idea, therefore, was abandoned. Both women thought that it was preferable to focus on providing food aid and evacuating children and vulnerable people from Madrid to Valencia. They also supported the establishment of children's camps in Catalonia and later, in France, in line with other services offered in collaboration with other organizations in the framework of Aid Switzerland. It was only at the end of the Civil War, in 1939, that Switzerland decide to offer shelter to Spanish children. ${ }^{7}$
For Regina Kägi-Fuchsmann, saying goodbye to her family was hard. Her trips to Africa had been far from danger-free, but now she was heading into a country whose cities were bombarded with artillery from planes with increasing frequency. Her son Uli, who was twelve, did not want to cry but he could not hide his fear (KägiFuchsmann, 1968: 143). Her arrival in Barcelona in May only served to confirm her worries. Not only did she witness her first air raids, but her stay there coincided, according to her writings, with the bloodiest fights ever to occur in the city (between May 3rd and 7th, PSUC and PCE communists fought against the POUM Trotskyites and the anarchists) (Kägi-Fuchsmann, 1968: 144145). During the days they spent in Barcelona, Anna Siemsen and Regina Kägi-Fuchsmann visited the Olympic Stadium which served as a makeshift accommodation for refugees from other areas of Spain; on another occasion, while eating at their hotel, they witnessed their first bombing. The alarm went off as they were having lunch: "The guests were more curious than scared. Most of them laid down their napkins and ran to the windows. The waiter calmed us: those were Italian planes, he said, which never hit the target. And while the noise of the planes was almost piercing one's eardrums, the waiter continued serving at the tables". Later, the representative of the republican government who was accompanying them told them that the bombs had fallen near the railway station, but that they had not destroyed it. They went there and saw a smoking hole and two ruined houses that were still burning under a cloud of debris and smoke. This is how they found out that the top floor of one of these houses had been home to a children's centre and that at least forty or fifty children and their carers had died. At that moment, they realized that: "The war was not a newspaper article but the horrible reality" (Kägi-Fuchsmann, 1968: 147-148). Joanna Bourke studied fear in 20th century wars and she explains how the air raids gave raise to numerous descriptions of fear among the British civilian population in World War II. The feeling of having survived an air raid and of having seen others dying, the fear it would happen again and the need to keep calm and collected are some of the characteristics of these individual stories. Other fears, such as claustrophobia, were equally important, to the point that some chose to not go inside the shelters. In any case, the anticipation of danger was sometimes more meaningful than the disaster itself (Bourke, 2005: 222-230). ${ }^{8}$

In Valencia, Anna Siemsen and Regina Kägi-Fuchsmann experienced the second air raid of their trip during a visit to a food distribution point for the displaced people living in the city. Their accounts of these events emphasize once again the fear that both were feeling and their need to protect themselves. As they were observing the long queues, the sirens started blaring. Everyone started screaming "Aviación, aviación" (the words are quoted in Spanish within the German text), but nobody left the queue. Anna Siemsen and Regina Kägi-Fuchsmann tried to find an air raid shelter until finally the driver of a streetcar told them to get in the vehicle. In the same "sarcastic 
and arrogant" tone as the waiter of Barcelona, he then explained that the attackers were Italian and not very successful at hitting their targets. Later that evening they were able to verify that the bombs had fallen by the beach without causing any victims. Their target had been the fuel warehouses located in the port. Only some fishermen's houses were affected. But as the months went on, the bombings carried out by Italian aviators continued, and with "the training of their German teachers" they started to become more and more accurate, so that the population "took to get off the streets immediately after hearing the alarm" (Kägi-Fuchsmann, 1968: 148-149). ${ }^{9}$ This development is diametrically opposed to what happened in the United Kingdom during World War II, where people tended to be more afraid of the air raid sirens at the beginning of the war rather than at the end, when they were only concerned if they heard the bombs as well (Bourke, 2005: 228).

Once in Madrid, Anna Siemsen describes how artillery fire woke them up at five o'clock in the morning as she was sleeping in her hotel on Gran Via in front of the Telefónica Building. Anna Siemsen was still sleeping due to her major hearing impairment. After Regina Kägi-Fuchsmann woke her up, they inspected the damages to the Telefónica Building, the original target of the artillery fire, but also those suffered by their hotel. The houses of Gran Via were partially destroyed. Regina Kägi-Fuchsmann wonders "why even describe these horrors" since everyone had seen or lived through similar events: "For us it was something new. These horrifying sights were something incomprehensible, incredible. Walking through the city centre was a nightmare". They decided to move to a different area, less exposed to enemy fire (Kägi-Fuchsmann, 1968: 150-151).

Anna Siemsen does not mention her tears over the bombing of Guernica and she does not speak about her own fear in dangerous situations such as the air raids. Her tears and what she thought when she first heard the news remain in the private sphere; they will not be commented upon because they are not how she wants to express mourning in her writings. Women's fears when confronted to dangerous situations are generally not described. The accounts focus instead on the reactions of Spanish and republican society to the air raids and on their strategies to overcome fear. Still, Anna Siemsen' book differs from the autobiography of her travelling companion, written years after the facts. Anna Siemsen bases her narrative on a deeper empathy and she pays attention to how Republicans mourn their dead, rather than to her own grief. Grief is the emotion that dominates most of the events she described, and what she wanted to impart to her readers is an emotion she shared with the Spanish population. The religious orientation of the book and its deep protestant roots exalt this grief to a transcendent dimension as Spain almost becomes the Holy Land of the Bible: a Mediterranean country of ancestral traditions, but turned towards the future thanks to the political action of the Second Republic (Siemsen, 1937: 20-23). The Guernica bombing is mentioned in different chapters and alluded to on different occasions: with short references in her chapter devoted to the border (Siemsen, 1937: 9) or with longer references when she talks about the children:

\begin{abstract}
"Everything that happened in Guernica and Durango was not absurd, but completely deliberate: a massacre of children infinitely worse than the Bethlehem legend. I remember a large assembly of Spanish people in Paris where the Basque Health Minister spoke in a very quiet way, with a sort of suppressed ardour, and how his speech was even more poignant because of that. But when he started to speak about the suffering and death of 'our little children' his voice broke. And it seemed to me that in his voice I was hearing the voice of the entire Spanish population; many wails and lamentations. Spain was crying for its children and it didn't want to be consoled" (Siemsen, 1937: 9, 33-34).
\end{abstract}

The most exhaustive description of the Guernica bombing is that of a child who witnessed the massacre, quoted in a chapter dedicated to the theme 'destruction' which thoroughly describes the fear and the horror felt during air raids. The letter is an example of the kind of children compositions practised in Republican schools during the Civil War, which were purposefully developed so that children could narrate their experiences and express their feelings. These writing exercises were then corrected by the teachers before being published for propaganda purposes (Sierra Blas, 2009: 95-123). In one paragraph of the same letter, the child says:

\footnotetext{
"Bombs were exploding everywhere, surrounding us with fragments of bullets and debris. We were choking on smoke and dust, and then he called us and told us to follow him and to run towards an open field. We hadn't even walked a hundred meters when a plane started to shoot uninterruptedly with a machine gun. 'Ow, ow' my uncle cried out suddenly, and he fell to the ground completely soaked with blood. We were so scared that we kept on running forwards blindly because bullets kept raining on us without pause" (Siemsen, 1937: 38).
}

The quote contributes to adding drama and authenticity to the text because the writer points out that, while she did not witness the bombing, she did seek out witnesses' testimonies (Siemsen, 1937: 9, 37-40). From the very beginning, the book makes frequent use of eyewitnesses' accounts, a style which recalls that of war correspondents. Anna Siemsen travels throughout the country and explains what she sees and experiences; when possible, she offers a personal testimony of the war catastrophes, and she adds other people's impressions when she does not witness the events herself. She considers it necessary: "I've witnessed the destruction of Madrid, Valencia, Barcelona and hundreds of towns in every part of the country; I've experienced air raids, and I've seen how bravely the local population withstands them" (Anna Siemsen (1937: 37-38). The inclusion of 26 photographs in the first edition of the book also serves as testimony, because it includes images of the victims of the different bombings and of those who have been displaced (Siemsen, 
1937: non-numbered pages at the end of the book). Guernica plays an important role in the chapter 'European Epilogue', which is dedicated to the importance of international politics to save the Republic and the Spanish civilian population (Siemsen, 1937: 83-88). The writer also considers artistic representations of the mourning for Guernica: there is a mention of Picasso's painting in the Spanish pavilion of the Paris International Exposition (which she visited), and whose symbolic meaning she discusses in the chapter 'Spanish Folly' (Siemsen, 1937: 61-64).

This exercise in shared grief is expressed in the description of the burial of a young soldier in Valencia. It is an example of how to work through grief as a community and the emotional repercussions of grief on those who are part of this ritual. The staging of the burial helps to reconstruct an identity threatened by the existential crisis implied by death and it helps the community to overcome both the collective tragedy of fear and the feeling of loss:

"There was a funeral procession through the streets of Valencia. It was led by a white funeral chariot pulled by four white horses, and both the coach and the horses were adorned with ostrich feathers. But the chariot was empty. The coffin was carried by four militiamen; behind them, people were carrying crowns - so numerous, sumptuous and beautiful they could only be a product of this country of flowers. And behind them there were countless soldiers and workers, all wearing their uniforms or the official (and very nice) attire of the Republic."

The ceremony was the funeral of a well-known comrade fallen at the front; the whole ritual bore an unmistakable similarity to children's rituals we used to organize in similar cases (when a bird died, or when a doll fell and broke into pieces and things like that). Also unmistakably similar to our feelings when we were children, were the feelings of those who felt grief: besides the authentic, real and profound pain for the loss of a companion and the fleetingness of all things earthly, there is a certain pride for having been invited to join such an important ceremony. In the deepest part of yourself, you bask in how solemn and ornamental you can be during such events."

The symbols of the ritual include elements that are clearly republican (for instance, the attire of the mourners - workers' overalls and the official Republican uniform); however, these elements also retain and transform forms of expression of traditional burials (crowns, chariots, flowers) while trying to distance themselves from Catholic rituals (for instance, by avoiding explicit religious symbols or the presence of the clergy). Thus, mourning becomes eclectic. ${ }^{10}$ Anna Siemsen pays attention to those aspects of daily life, especially in the rural world, which to her seem archaic and ancient; that is to say, bearing the signs of a strong relationship with the past. At the same time, however, she underscores how these rituals are modified and adjusted, like those of the urban areas, so as to better conform to modern republican ideals. Her book includes frequent reflections upon Spain's history and its religious customs and how they correlate to Marxist revolutionary schemes. Ever since the Age of Enlightenment,
Europeans travelling through Spain had described a poor, underdeveloped country (Bolufer Peruga, 2003: 255$300)^{11}$, but Anna Siemsen challenges that vision by describing this situation as the result of class struggle. She sees the country as a feudal system which has not managed to develop into a fully capitalist society. ${ }^{12}$ In her view, Spain is a rural country of small independent merchants: "it is not a capitalist country, but rather a country exploited by capitalism; or, even more, a colony" (Siemsen, 1937: 19).

Another strategy to cope with the fear caused by air raids and soldiers dying at the front was escapism in one's leisure time. Anna Siemsen observes the reactions of the audience in a cinema in Valencia. The city was an air raid target and the population was suffering from food shortages. At first sight, everything seemed to be rather depressing. But the cinema was crammed with young militiamen and their girlfriends. Six well-known Disney movies were shown: "Mickey Mouse, Three little pigs, The wolf and seven young goats, The fight of the roosters." In the intermissions, a newsreel was broadcast, announcing the most recent events in Spain: "the inauguration of a school, displaced people, the interrogation of prisoners and (most striking of all) the bombing of Madrid." For Anna Siemsen, it was difficult to imagine how "six Disney movies could be seen in a row"; but what she found most interesting was how focused the young adults in the theatre were: "A group of nine-year-old children could not have laughed in a more sincere and captivated way. They were fully absorbed and completely oblivious of their own selves" (Siemsen, 1937: 28).

Besides the escapism provided by American cartoons, she is also interested in the plays put on by communists in a besieged and bombed-out Madrid. These were works designed to function as propaganda, whose objectives were to boost civilians' morale and to recruit volunteers to defend city. In the chapter 'Propaganda', she quotes long passages from a pamphlet bound like a notebook, the "historical documents of 5th regiment of Madrid". It was called "Street theatre". In her prologue, we learn that the play was staged in the streets of Madrid "on the back of a truck". She explains that it was part of the Republican propaganda, which made use of several other methods: "leaflets, posters, meetings in streets and squares, the launch of bombs filled with leaflets, etc." The goal was to recruit more troops to stop the advance of the insurgents. The play was performed in the most densely populated neighbourhoods of Madrid, and also outside factories and industries. Anna Siemsen compares this kind of theatrical production to the one developed by the Soviet Union. She also describes the photos of the front page of the notebook, which portrayed the audience surrounding the truck where the actors were playing and very blurred scenes of the play itself. To her, the faces of people in the audience seemed "moved, furious, thoughtful, entertained." And all of them were very actively involved (Anna Siemsen, 1937: 67-68).

She then translates the play and reproduces it in its entirety (Siemsen, 1937: 69-74). It is centred on four 
shock battalions, and there are eight characters, some of them members of the battalions; at the end of the play, they encourage the audience to enlist. It is not the sort of play whose goal is to educate through clever metaphors; instead, it uses drama to convey a very clear message (Holguín, 2002: 183-186). For Anna Siemsen: “Despite being such simple works displaying all the consequences of a very rushed writing, they may be the best way to understand what is happening today in Spain, and specifically the constant need to switch between tasks which are all extremely urgent."

Along with fear and grief, another of the emotions that Regina Kägi-Fuchsmann and Anna Siemsen share is indignation; however, they communicate it in different ways. Both consider it unacceptable that civilians should die in the bombings, that many of them are children, and that no one seems able to put a stop to the killing. Regina Kägi-Fuchsmann relates an anecdote about her son Uli to explain, through dialogue, how this feeling of indignation takes hold in a person who learns about the death of innocent people during a war and how it generates a great deal of frustration. She explains how she came back home and told her husband about the first bombing in Barcelona and the destruction of the children's centre she and Anna Siemsen both witnessed and in which at least forty or fifty children and their caregivers had died. Her son was in the kitchen with his nanny listening to his parents' conversation and helping her to dry the dishes, but suddenly he came into the living room and threw the drying cloth on the floor, wailing that he did not want to help his nanny anymore. He had asked the woman what she thought of what his mother had just related, and the nanny, a young and very religious woman, had answered that the ways of God are inscrutable and that perhaps the children had paid with their lives for the sins of their parents. The child did not accept this reasoning and wondered in anger what kind of God would allow an innocent to pay for the sins of others. Regina Kägi-Fuchsmann explains that she managed to calm her son down, but his question was still on her mind when she found herself looking at images of the victims. With this anecdote, the author turns the indignation caused by the bombings into a theological dilemma about the divine tolerance of evil in the world (Kägi-Fuchsmann, 1968: 148). In other passages, Regina Kägi-Fuchsmann endorses not only the Swiss humanitarian aid provided to the republicans but also the Swiss volunteers who fought to protect the Republic, because they believed in democracy and freedom. The air raids carried out by German and Italian troops and the ambivalence of the European powers were cause of much indignation in people of good faith or politically aware, but also justified, in their view, the volunteers' choice to fight with the Republic.

Anna Siemsen feels indignation and she tries to explain it by collecting texts from Spanish writers and relating her conversations with the Spanish authorities and with those intellectuals who complain about the unjustifiable isolation of the Republic among European democracies as a result of the Non-Intervention Agreement. ${ }^{13}$ In the chapter 'Spanish Folly' she begins by mentioning the inauguration speech of the pavilion of the Republic at the Paris International Exposition in July 1937 to show "how the Spaniards see themselves". ${ }^{14}$ This was the speech of philosopher José Gaos, dean of the Complutense University of Madrid and general curator of the pavilion, who explained the objectives of the pavilion in which Picasso's Guernica was exhibited: "It is not a question of representing the intelligence of the Spanish people but its character, its ethical nature which refuses to understand that reality may not correspond to the ideal". As in other chapters of the book the author focuses on the existence of a "character" of the "Spanish people" that she describes in accordance with José Gaos' vision: a character with little inclination for technical things, that of idealistic people who are, therefore, "not very sensible", "obsessive", "obsessed with an ideal" and dreamers. The ideal is "that of a regime based on peaceful and free self-determination of the people". And she ends by using the literary example of Don Quixote, who only comes to his senses and adapts to reality when he is close to death. It is in this way that she rationalizes the struggle of the people, insisting that the Spanish are incapable of "submitting once and for all to infamy, cowardice, the grotesque of a false reality". Anna Siemsen praises the Spanish pavilion, which she visited, for being the only one to tell the truth about what was happening in its country avoiding the "coquettish game of hide and seek" other countries were playing in their own pavilions. Moreover, she connects José Gaos' words with a discussion held in Barcelona by the Spanish authorities and a group of intellectuals who had complained about German and Italian intervention and who had questioned how European democracies were both providing humanitarian aid "while at the same time closing their borders and not allowing weapons through, the only thing we actually want from them". Anna Siemsen's response to this is that the European governments are perfectly aware of the situation, but "they fear war" and - for the purposes of a clean conscience - they express their sympathy and send humanitarian aid: "They are, purely and simply, afraid of dying because of the war; you have to understand it". Someone answers that what Hitler and Mussolini are doing in Spain is securing their position so they can strike other European states next and their plan is to invade France from Germany and control the entire Mediterranean from Italy. ${ }^{15}$ For a moment, there is no reaction to this; and then another Spanish intellectual loses his temper and shouts that they need to fight to the bitter end against the invaders and to keep hope. Anna Siemsen considers that this lack of common sense and this character (obsessive in its nature) can contribute to saving a world which is "on the edge of the precipice because its excess of common sense" (Siemsen, 1937: 6164). That is to say, given the extreme situation the Republic is facing because of the aggression of the insurgents and their international allies, the European democracies' passive response cannot be the solution and constitutes "an excess of common sense". She feels, then, empathy for the indignation of the people she is talking to. But she also warns of the danger of an argument based only on 
rejection of foreign intervention of any kind in Spain, since this will inevitably lead to xenophobia. For the Swiss humanitarian aid workers it was essential to receive a positive welcome from the population. In the book, Anna Siemsen remembers that in the spring of 1937 "people were still pleased with the arrival of foreign evacuation trucks, greeted them with cries of 'Long Live, Switzerland! Long Live, England!'” But she wonders if people still feel the same at the time of writing. In her view, the best way to avoid xenophobia and explosions of chauvinism is effective volunteer relief effort as proof that "among people who love freedom and humanitarianism there is a solidarity against the barbarities of the belligerent dictatorships of terror" (Siemsen, 1937: 61-64).

\section{Empathy with the displaced}

Before leaving for Spain, Regina Kägi-Fuchsmann wondered what they could do "with their weak forces" to contribute to the humanitarian effort, whether they could organize the transportation of children to Switzerland and what forms of aid would be necessary. Her empathy with the Spanish republicans led her to wanting to help the civilian population subjected to the air raids. Anna Siemsen also felt a great empathy for the Spanish population who was experiencing the Civil War in the republican zone. She mentions it in the very foreword of her book: "My testimony may be biased because it is born from a profound love and has no other purpose than that of awakening love, the type of love that arises from veneration for intense suffering and struggle, from the joy of contemplating human beauty and from gratitude for the gift of unexpected and impressive camaraderie." Despite the differences in their viewpoints, the two shared many values and the intellectual and emotional ability to empathize with the displaced. If they felt sympathy for the Republic, it was not only because of the civic, social and democratic values it represented, but also because of their training as educators and their interest in psychology (especially child psychology), which had helped them to develop the ability to feel a profound empathy for other people. In this sense, they were part of the same emotional community. ${ }^{16}$ Even so, their individual emotional history left a strong mark on their attitudes and perceptions. Regardless of the values they shared on moral and ideological grounds, the cultural practices they witnessed in Spain decided the extent to which those values could be applied: in theory, as volunteers for the Swiss humanitarian aid, their empathy should have been directed towards the entire civilian population living in the republican zone; in practice, however, that feeling had a somewhat selective character. Their personal faith provided an important impulse for their intercultural empathy, but, at the same time, it defined its limits. For instance, Anna Siemsen found it difficult to empathize with Spanish Catholics priests for historical reasons and Regina Kägi-Fuchsmann could not avoid making comparisons between displaced Spaniards and Jewish refugees from World War II. One of the challenges they faced was how to incorporate what they observed in Spain within their ideal concept of humanitarian aid. To that end, it was necessary to try to understand emotional responses which were culturally different from those they were familiar with.

Regina Kägi-Fuchsmann describes how she felt during her visit to the Olympic stadium in Barcelona which served as shelter for displaced people from other parts of Spain. The refugees were living in the changing rooms, in the showers and in the spaces intended for sport exercises. Most of them were women, children and elderly people surviving in abject misery because they came from remote areas and had not had access to adequate means of transport. The men were looking for a job in the city. Kägi-Fuchsmann was struck by the silence of the displaced in the stadium, by their "passive attitude, how they were sitting next to their bundle of clothes, without showering," and by their lack of hygiene. They were only given food: "There were lentils and wine." Next, she compares this passive attitude to that of the refugees she had seen in many camps during World War II and in the post-war period: "In none of them have I seen a crowd of people so crestfallen, so lacking in energy." She offers the example of a woman staring into the void, a baby in one arm and a cage with a dead bird in the other. From this, she concludes that "people who have been displaced were more affected the more primitive and humble they were." According to her, the people she saw in the Olympic Stadium lacked the intellectual and emotional tools to protect themselves. She then draws a comparison with the concentration camps in the South of France from 1941 to 1944 and specifically that of Gurs. There, despite the fact that living conditions were worse than in Barcelona, the people organized themselves to improve their situation; according to her, they even offered cultural activities, from music concerts to educational courses. In addition, she mentions examples of the Jews from Alsace-Lorraine and the Germans who were living there: "I will never forget the touching Jewish religious service that was performed in a miserable barrack on Friday night." The prayers of the rabbi and his community moved her deeply. The description of these events and her thoughts about them are consistent with the stereotypes which assign displaced people a passive role, something that is very common in refugee history (Gatrell, 2015). On the other hand, however, she makes use of this stereotype only in the case of the refugees from the Spanish republic, thus establishing a categorization according to cultural origin. Her childhood in a Jewish family and her experiences of World War II lead her to establish a hierarchical and retrospective empathy in which the groups closer to her are recognized as more active - contrasted with those of the Civil War, which are more passive.

Anna Siemsen describes the visit to the displaced people of the Barcelona stadium in a different way and sees it under a different light. Throughout her book, she provides numerous figures of the numbers of refugees in the republican zone in relation to the population of the main foster cities to highlight the magnitude of the humanitarian catastrophe: "One million in Catalonia, three hundred thou- 
sands of them in Barcelona. Valencia has 300,000 residents and 350,000 refugees, Alicante 512,000 residents and 60,000 refugees, Ciudad Real 127,000 residents and 12,000 refugees, etc." (Siemsen, 1937: 34). She analyses in great detail the situation of the transport infrastructure, which she defines as backward and very affected by the war because of the difficulties in finding fuel for the trucks, a factor that makes it much harder to provide any kind of humanitarian aid (Siemsen, 1937: 35-37). What she says, however, is that despite everything, the commitment of the citizens, and especially of the women, to the Republic makes it possible to move the displaced to the cities in the best possible conditions; afterwards, the refugees are reassigned among the rural populations where they are welcomed with great solidarity and hospitality. All of this is managed with great effort by unions and cooperatives (Siemsen, 1937:44-45). For Anna Siemsen, the reaction of the displaced shows remarkable endurance and provides examples of individual attitudes of enormous devotion and heroism among the population who foster them. She does not speak about the passivity of the displaced, but rather of their difficult situation and the enormous effort of the civilian population in the face of the challenges posed by war. Women are no longer at the front, like militia women were at the beginning of the war (something which Anna Siemsen deplores); instead, they work and provide help in the rear-guard: "What can be observed in the Republic are women who work hard and suffer a lot, brave comrades of their brave husbands." She names many women who were well-known for their role in politics, but is careful to place a particular highlight on the work of all the unknown women: "Under Franco's bombs they did their household chores, took care of the children, carried on with their tasks and helped one another" (Siemsen, 1937:29-32).

However, her empathy is not directed towards other categories of people - for instance, the Catholic clergy in the Republican zone. In the book, she strived to present the Republic as liberal and tolerant towards religion and denied the existence of any religious persecution against the Catholic Church (although she does recognize cases in which the churches have been closed down or even destroyed). ${ }^{17}$ She has a very negative vision of the role of the Catholic Church in Spanish history. The most important person she talks to on this subject is a German Protestant pastor living in Madrid (Siemsen, 1937:48-53). In the chapter 'Adversaries', which examines the opponents of the Republic within the republican territory, she describes how some seminarians had been re-educated in a farm near Barcelona run by two young women. Among other things, they encouraged the young men to dance with one of them, which went against their faith. For Anna Siemsen, this type of re-education is praiseworthy and an example of the patience and wisdom republican authorities display towards their adversaries (Siemsen, 1937:72-74).

Regina Kägi-Fuchsmann observes the distribution of food for the displaced in front of a convent in Valencia. There is a riot, and policemen are forced to intervene to prevent people from attacking each other. It is the first time she sees people ignoring a queue in Spain; to her, this episode represents a polar opposite of the discipline she witnessed in the queues in Madrid. She compares this "sinister" lack of organization with the "order and fairness" that the Swiss Children's Aid managed to introduce later on, during their own food distribution in Valencia (Kägi-Fuchsmann, 1968: 148-149). For Anna Siemsen, on the other hand, the problems during the distribution of food in Valencia are as remarkable as the fact that inside the convent there was a "peaceful, spacious, and cool dining room", with a "big kitchen" with giant stoves under the control of a cordial and competent chef. She goes on to add that this is not an exception, because "hotels have also been socialized and are extraordinarily well managed by the unions, which consider that helping the refugees takes second place after the providing for the Army. They do what they can" Anna Siemsen (1937:42-44).

As they were organizing their journey, a central question for Anna Siemsen and Regina Kägi-Fuchsmann was how to organize an evacuation of Spanish children to Switzerland and what forms of aid would be necessary. They had discussed civilian evacuations from Madrid to other cities, collaboration with the children camps, food distribution etc. As a result of their professional training as educators and their interest in psychology, especially child psychology, the possibility of evacuating children posed a series of theoretical and practical dilemmas, ${ }^{18}$ namely the children's emotional needs that would arise once they were separated from their families. In order to solve this, it was necessary to understand the difference between evacuating children to a foreign country and simply moving them to other areas of the republican zone; what emotional role would be assigned to the state and to the families during the evacuations; and finally what pedagogical model would be appropriate to make the children feel welcome in the camps.

Both Regina Kägi-Fuchsmann and Anna Siemsen soon concluded that at that moment, an evacuation of the children to Switzerland did not make sense because of pedagogical and political reasons. Anna Siemsen states: "In the spring, when there was a proposal to the government of Valencia to send the children of the refugees abroad, the Valencian Government answered: the Spanish people want their children to stay with them so they can share the destiny of their parents and their people and will not feel abandoned in unfamiliar surroundings where people may not understand them, a situation far worse than the lack of basic necessities." What was still assumed back then was that the Republic could win and therefore evacuating the children to Valencia was the best solution. When mentioning the experience of the Basque children who had been evacuated to England, Anna Siemsen considers that they were in a situation of "terrible misery" because they had been taken "to strange lands incomprehensible to them" and because there they had to listen to the British Government lying about the Republic. Moreover, she notes: 
"From time to time we hear news of Basque children in England staging protests, escaping from the camps and even trying to hide in a foreign country, where there is no compassion towards them. It is cruel to force them to stay there, but it is even more cruel to return them to a country dominated by the enemy and which, therefore, has become more foreign than any other foreign country could be. Of all the torments refugees have to endure, this seems to me to be the deepest and incurable."

She adds in a footnote that she does not want to judge how the children have been received in England because she is unfamiliar with the details of that process. What she thinks, however, is that embracing the hospitality of a country that is among those responsible for the "tragedy" of Spain is, in her opinion, "more bitter than death itself" (Siemsen, 1937:41-42). Regina Kägi-Fuchsmann also notes that the refusal of the Swiss authorities to welcome Spanish children at those times was understandable and well argued (Kägi-Fuchsmann, 1968:152).

Anna Siemsen and Regina Kägi-Fuchsmann agree that evacuating the children from Madrid to Valencia should be the priority of the Swiss humanitarian aid; both are concerned about transport problems, not to mention accommodation and supplies issues related to any evacuation of a civilian population: lack of milk, bread, underwear, bedclothes, medicines, soap and toys. Anna Siemsen writes they should "bear in mind what it means to feed millions of displaced people", but she also stresses that Spain is "a vast and beautiful" country, with enough houses and "many dedicated caregivers and educators" supported by the republican Government. The author further acknowledges the sense of loss and uprooting which is a feature of populations forcibly displaced by war, especially in the case of children separated from their families. On the other hand, however, she describes the positive role of both the State and the humanitarian organizations in the evacuations, and particularly their effort not to separate families. According to the management report of the Ministry of Public Education she refers to and whose development says she verified herself, the role of the teachers is crucial:

\begin{abstract}
"Teachers should act as a link between parents and guardians; they should provide information about the situation of the children, as well as help the children with their correspondence. Whenever possible, they should ensure that those families who have been separated can be reunited, that siblings can stay together, and that during their free time the children interact with one another (Siemsen, 1937: 48)."
\end{abstract}

The emotions of the displaced children and their parents, particularly, the fear of loss, were the object of a propaganda war on both sides. Evacuating the children to the camps was questioned by insurgent propaganda, which did not recognize the legitimacy of the republican Ministry of Public Education and denied proper procedure had been followed. The Ministry, on its part, defended its evacuation policy and the transformation of the children camps (originally built for holiday periods) into centres of permanent residence for as long as the bombings lasted: of the 558 children camps in 1937, 406 were family camps (i.e., children lived with their families), and 152 were collective camps (i.e., children were placed under the care of the camp's manager, teachers and auxiliary staff) (Sierra Blas 2009: 83-94). Both authors were in favour of these measures both for political and pedagogical reasons. They had a fundamentally positive vision of the role of the State in the educational field, extending to the schools in times of peace and also the children camps during the war. They assumed that forming future citizens presupposed a public and republican education. Their ideas on the emotional needs of children did not prevent them from supporting State intervention and the establishment of the camps so as to counter the risk of living in cities besieged by air raids.

For Anna Siemsen, the people who best embodied the feeling of empathy towards the evacuated children and an exemplary pattern of behaviour in humanitarian aid within the framework of the evacuations are the wife of a doctor from Barcelona who runs an orphanage in Puigcerdá and a hotel entrepreneur from Madrid whose hotel was seized and who coordinates schools and children camps in Valencia. Although she chooses not to name them, as she does with everyone else mentioned in the book, the volunteer is identifiable as Ramón López Rumayor Lombera. ${ }^{19}$ For Regina Kägi-Fuchsmann, on the other hand, the person who best embodies the values of the humanitarian aid is the Swiss Rodolfo Olgiati, who, since 1934, had been the secretary of the Schweizerische Vereinigung für Internationalen Zivildienst (Swiss Union for International Service). Olgiati was also at the helm of Swiss Aid, an alliance of 14 organizations that based on their size and function fulfilled relevant tasks. ${ }^{20}$

From the way Anna Siemsen describes the woman managing the orphanage in Puigcerdá and the hotelier Ramón López Rumayor Lombera, it is clear that both could have continued to lead a comfortable life, but they chose to join in the efforts to help evacuated children. It is for this reason that they embody the values the author had singled out in one of the most important articles to understand her opinion about emotions and education, whose subject is "psychological conditions for socialism" (Siemsen, 1924) It explains that the educational effort should contribute to social change by helping people to understand the essential difference between discipline and responsibility and encouraging them to behave responsibly. Discipline is the product of the needs of capitalist companies and, from a psychological standpoint, it works because of external pressure and a hierarchical obligation. Responsibility, on the other hand, is a consequence of one's mindfulness of the community to which one belongs. Responsibility is learned in school; it is born from decisions taken freely and serves to solve specific tasks together with others. In this sense, the two people mentioned above embody and instil in others that sense of responsibility. When talking about the director of the orphanage, Anna Siemsen says: 
"A few days later we saw her up there, a young, beautiful and very popular woman; she would have had every reason to lead a very spoiled life. But at that time she was living alone, in an elegant house, old but very uncomfortable, with thirty children who had just fled from Madrid. She only had two assistants, this was all. But over four days she renovated the house, which had been in a bad state: she had painted it and furnished with pieces requisitioned from elsewhere. The children had beds (which were still lacking bedclothes), meals (although, of course, they ate in two shifts because there was not enough crockery yet), but above all they had affection and motherly care and were constantly looked after (Siemsen, 1937: 30-31)."

When talking about the activity of Ramón López Rumayor, she quotes him as he enthusiastically enumerates some of his many tasks:

"In Madrid we have very good reformed schools. I'm sure you must have heard of Lorca (sic). I'm going to show you his school, which is no longer in Madrid; its founders have fled. All of this worried me a lot. And now there is so much to be done in this country. The Ministry cannot do everything. That is why I go the villages and inspect the schools. Some of them are well-equipped. But very often schools lack everything, especially basic necessities. In those cases I go find the mayor and discuss the issue with him; I explain that for a village like his the classroom is too small (Siemsen, 1937: 58).”

What emerges from Anna Siemsen's writings is that López Rumayor was not only very committed to helping the evacuated children, but also fascinated by pedagogical reforms and particularly by the work of the Family Education Communities founded by Angel Llorca in El Perelló (Valencia) in January 1937. Llorca established a third type of children camps, in addition to the family model and the collectives, which features a type of intimacy one can find in a family but the atmosphere of a school (Sierra Blas, 2009: 92). ${ }^{21}$

\section{CONCLUSIONS}

Anna Siemsen and Regina Kägi-Fuchsmann express their emotions in conformity with the humanitarian ideas and grant the same value to the emotions of the victims of the Civil War. How they express their emotions makes it possible to place them within the same emotional community. As they witness the air raids against the civilian population, they both feel fear, grief and outrage. But their vision of Spain and their concept of humanitarian aid also present distinct characteristics. Their own past experiences as refugees and the solidarity they feel towards the other refugees who were arriving in Switzerland at the time allow them to react with greater empathy and altruism to what they see in Spain. They know perfectly well the sense of loss caused by war and political persecution. For them, SAH is both a refuge and an emotional community, where they can share their values with others and organize the Swiss humanitarian aid.
Both cases indicate that fear is a basic emotion during wars, but also that this emotion affects those volunteering for humanitarian relief efforts in a specific way. Anna Siemsen and Regina Kägi-Fuchsmann's expressions of fear and their perception and interpretation of the war situation differ from how combatants and the civilian population express the same emotion. The tools and instruments the two volunteers use to overcome fear are based upon those values of empathy that had led them to participate in the humanitarian effort. Emotions such as grief for the death of civilians or outrage at the bombings are proof of that empathy. At the same time, the two authors observe how soldiers and civilians react to situations of danger and how the opposing political powers try to manage fear and empathy in war. What attracts their attention is particularly what artists make of war, and how their works are received by the political elites and the Spanish population: they discuss Picasso's Guernica, the propaganda theatre in the streets of Madrid, and the reaction to American animated movies broadcast in the middle of the war in a cinema of Valencia. To counter the spreading of fear, humanitarian aid tries to build up empathy and altruism. This empathy is expressed by different symbols and through complex practices. The evacuation of children from Madrid to Valencia is the best example of the dilemmas and conflicts the volunteers have to face. The fear that children will be separated from their parents, exploited by insurgent propaganda, is allayed by organizational measures and pedagogical ideas about the role of the school and the establishment of the children camps. In short, the journey to Spain helped both women to have a clearer picture of the activity of Swiss humanitarian organizations and to get to know Spanish and Swiss volunteers and helpers in situ; furthermore, it also contributed to giving them a better understanding of their own emotions and reactions, and was useful to develop solutions for problems that occurred on a day-to-day basis. The end of the war did not bring about the end of emotional and practical issues, but the situation did change. After the victory of the insurgents in Spain, a large number of refugees made their way to the South of France through the Pyrenees in a few days, both civilians and soldiers. Most of the work was now carried out in France, mainly because it wasn't possible to repatriate the refugees in any efficient way and the desire of many to go to Mexico would only be feasible much later. Thus, SAH put an end to its projects in Spain and sought resources to support the children camps in France. Regina Kägi-Fuchsmann continued to take part in the relief effort through her role as manager of SAH; Anna Siemsen, on the other hand, returned to her academic work, which remained focused on topical issues.

\section{ACKNOWLEDGEMENTS}

This article is part of a project carried out thanks to the research programme "Ayuda humanitaria europea en Francia durante la Segunda Guerra Mundial" (European Humanitarian Aid in France during World War II); Reference: HAR2014-58043-P funded by the Ministerio de Economía y Competitividad of the Spanish government. 


\section{NOTES}

* Translated to English by Martina Willimann.

1 On Spanish exile from the point of view of the history of emotions and emotional suffering of the exiled see Rodríguez López, Carolina; Ventura Herranz, Daniel (2014: 113-138). Other approaches to the Civil War from the point of view of the history of emotions are: Moscoso, Javier (2016: 176-191) and on the period of the Second Spanish Republic are: Krahuel, Javier (2016: 141-158).

2 On the sociology of emotions in societies that are currently undergoing armed conflicts: Serrano Sanguilinda (2010). On the role of emotions in German social democracy from 1863 to 1933 see Hake (2017).

3 On compassion and empathy as key emotions of the humanitarian rhetoric since the middle of the 19th century, and particularly in relation to Henri Dunant' texts and the foundation of the Red Cross see: Taithe (2006: 79-99).

4 On selfishness in the Republican faction as opposed to altruism see Seidman (2002). Concerning the Swiss humanitarian aid during the Civil War in the Swiss political context see Farré (2006: 69-92, 135-149, 192-204) as well as Rodríguez (2001: $51-56,130-144)$. On the political and diplomatic context see also Gavira Brandt (1991), Moral Roncal (2005) and Trinidad Lafuente (1999). For a detailed description of the Swiss aids campaigns see Schmidlin (1999: 55-123). On humanitarian aid in the Civil War and Swiss aid in particular see also Expósito Navarro (2014), Petrus (2013) and Schmöller (2017).

5 Regina Kägi-Fuchsmann 80 Jahre alt, in: Neue Zürcher Zeitung, 9.5.1969.

6 Anna Siemsen's book was published in German twice: the first time by Editions nouvelles internationales - Internationale Verlag-Anstalt in Paris in 1937, 112 pages, and in the Komet-Verlag in Düsseldorf in 1947, 145 pages. The number of copies published is unknown. Regin Kägi-Fuchsmann's autobiography appeared in 1968 in the Ex Libris Verlag in Zürich, 336 pages. The chapter devoted to the Civil War is only 26 pages long (133 -159). On evolving views about the Spanish Civil War during the decades following the conflict see Weber (2010). On the personal testimonies sand the trials to which the Swiss Brigadists were submitted see Calvo Salgado (2009). On the participation of foreign nurses in humanitarian aid see Martín Moruno and Ordóñez Rodríguez (2009)

7 On the evacuations of children during the Civil War see Alted (2003: 43-58). On evacuations in general from Toledo and Madrid see Sánchez-Collado Jiménez (2015).

8 On the bombing of Catalonia and its consequences see Dueñas Iturbe (2013)

9 On the bombing in Valencia see Díez Pomares (2016).

10 On the continuities and changes in mourning rites in the Mediterranean area from Antiquity to the present and their evolution in Spain see: Amelang, (2005: 3-31).

11 On the travel accounts of British supporters of the Republic during the Civil War see: García (2008).

12 On the presentation of the republican propaganda of the Civil War as a struggle between feudalism and progress and its echo in British public opinion see: Hugo (2008: 129-130).

13 About this argument on the accounts of British travellers supporters of the Republic see: García (2008: 131-132).

14 The word "Vernunft" in German means both 'common sense' and 'reason' (in the reference, for instance, to the Age of Enlightenment). „Unvernunft“means 'folly' and 'without reason'. The term 'common sense' is central to the philosophical and pedagogical thought of Anna Siemsen.

15 Anna Siemsen deepens this threat analysis of the possibility of WWII in her final chapter of the book ('European epilogue'); in it she is broadly in line with the argument of her brother's book on the Germanic Empire as a danger to Europe.

16 On the differences of style in the same emotional community see: Rosenwein (2006: 100-109).
17 It coincides with the same pieces of republican propaganda collected by English travellers: García (2008: 158-164).

18 On these kinds of dilemmas and the different solutions to problems arising from the evacuation of children in France and England during the WWII see: Downs (2016: 121-150; 2011: 413448), Fernández-Fontecha (2016).

19 At the end of 1936, he moved to Valencia where he was the Director General of the Kindergartens and ensured the creation of the school camps for the refugee children in the provinces of Levante. See: http://www.fpabloiglesias.es/archivo-y-biblioteca/diccionario-biografico/biografias/30199 lopez-rumayor-lombera-ramon.

20 The Swiss Aid was the central organization founded in 1937 (German: Schweizerische Arbeitsgemeinschaft für Spanienkinder (SAS), Swiss working group for Spanish children). On the author Rodolfo Olgiati see: Schmidlin (1999: 57-106, 115-122).

21 On the school colonies see also Fernández Soria (1987) and Crego Navarro (1989). On Angel Llorca see Del Pozo Andrés (1987).

\section{REFERENCES}

Alted, Alicia (2003) "Los niños de la Guerra Civil". Anales de Historia Contemporánea, 19: 43-58.

Amelang, James (2005) "Morning becomes eclectic: Ritual lament and the problem of continuity". Past and Present, 187, May: 3-31.

Bauer, Alexandra (2012) Das Leben der Sozialistin Anna Siemsen und ihr pädagogisch-politisches Wirken. Eine historische-systemische Studie zur Erziehungswissenschaft. Peter Lang, Frankfurt am Main.

Bolufer Peruga, Mónica (2003) «Civilización, costumbres y política en la literatura de viajes a España en el siglo XVIII». Estudis, 29: $255-300$

Borst, Eva (2000) «Das einmal erworbene Bewußtsein bleibt unverlierbar". Annäherungen an Anna Siemsens Erziehungstheorie». In: Weder erwartet noch gewollt. Kritische Erziehungswissenschaft im Kalten Krieg, edited by Eierdanz, Jürgen and Kremer, Armin. Schneider -Verlag Hohengehren, Baltmannsweiler: 69-90.

Bourke, Joanna (2005) Fear. A Cultural History. Shoemaker and Hoard, Emeryville.

Calvo Salgado, Luís Manuel (2009) «Medios audiovisuales en la enseñanza universitaria de la historia. Análisis del documental: Hans Hutter: un suizo en la guerra civil española». Espacio, Tiempo y Forma, Serie V: Historia Contemporánea 21: 37 - 57.

Crego Navarro, Rosalía (1989) «Las colonias escolares durante la Guerra Civil (1936 - 1939)». Espacio, Tiempo y Forma, Serie V: Historia Contemporánea 2: 229 - 328.

Del Pozo Andrés, María del Mar (1987) «Angel Llorca: un maestro entre la Institución Libre de Enseñanza y la escuela nueva (1866-1942)». Historia de la educación: Revista interuniversitaria, 6: 229-248.

Díez Pomares, Gaspar (2016) «Los bombardeos italianos sobre el País Valenciano durante la Guerra Civil española: un estudio fotográfico». Revista de Historia Contemporánea, 15: 181 - 202.

Downs, Laura Lee (2016) "Au Revoir les Enfants: Wartime Evacuation and the Politics of Childhood in France and Britain, 1939-45". History Workshop Journal, 82, Issue 1, 1 October: $121-150$.

Downs, Laura Lee (2011) "Enfance en guerre : Les évacuations d'enfants en France et en Grande Bretagne, 1939-1940". Annales, H.S.C., mai-juin: 413-448.

Dueñas Iturbe, O. (2013) La gran destrucció. Els danys de guerra i la reconstrucció de Catalunya després de la guerra Civil (1937 1957). Tesis historia contemporánea. Universitat de Barcelona.

Expósito Navarro, Luis Manuel (2014) "La ayuda hunanitaria en la Guerra Civil española. El comité de Ayuda Suiza a los niños de España”. In: Tiempos de exilio y solidaridad: la Maternidad Suiza de Elna (1939 - 1944), edited by Alted Vigil, Alicia and Fernández Martínez, Dolores - UNED, Madrid, 61 -88.

Farré, Sébastien (2006) La Suisse et l'Espagne de Franco. De la Guerre Civile à la mort du dictateur (1936-1975). Editions Antipodes, Lausanne. 
Fernández-Fontecha, Leticia (2016) "Imagining the uprooted child: pain, evacuation, and the World War II". In Body between Materiality and Power.Essays in Visual Studies, edited by Jiménez del Val, Nasheli. Cambridge Scholar Publishing, Newcastleupon-Tyne: $79-94$.

Fernández Soria, Juan Manuel (1987) "La asistencia a la infancia en la Guerra Civil. Las colonias escolares". Historia de la Educación: revista interuniveristaria, 6: 83 -129.

García, Hugo (2008) Mentiras necesarias. La batalla por la opinión británica durante la Guerra Civil. Editorial Biblioteca Nueva, Madrid.

Gatrell, Peter (2015) The Making of the Modern Refugee. Oxford University Press, Oxford.

Gavira Brandt, Martín (1991) Suiza y la guerra civil española. Tesis Universidad Complutense de Madrid, Madrid.

Hake, Sabine (2017) The Proletarian Dream. Socialism, Culture, and Emotion in Germany, 1863-1933. De Gruyter, Berlin.

Holguín, Sandie (2002) Creating Spaniards. Culture and National Identity in Republican Spain. The University of Wisconsin Press, Madison.

Kägi-Fuchsmann, Regina (1968) Das gute Herz genügt nicht. Mein Leben und meine Arbeit. Verlag Ex Libris, Zürich.

Krahuel, Javier (2016) "The Battle for Emotional Hegemony in Republican Spain (1931-1936)". In Engaging the Emotions in Spanish Culture and History, edited by Delgado, Luisa Elena, Fernández, Pura and Labanyi, Jo. Vanderbilt UP, Nashville: 141-158.

Martín Moruno, Dolores; Ordóñez Rodríguez, Javier (2009) “The nursing vocation as political participation for women during the Spanish Civil War". Journal of War \& Culture Studies, vol. 2, $\mathrm{n}^{\circ} 3$ : 305-319.

Moral Roncal, Antonio Manuel (2005) "El auxilio diplomático suizo (1936-1939): Humanitarismo y neutralidad benevolente en la Guerra Civil Española". Cuadernos de Investigación Histórica, 22: 349-372.

Moscoso, Javier (2016) "From the History of Emotions to the History of Experience: The Multiple Layers of Material Expressions". In Engaging the Emotions in Spanish Culture and History, edited by Delgado, Luisa Elena, Fernández, Pura and Labanyi, Jo. Vanderbilt UP, Nashville: 176-191.

Petrus, Gabriel (2015) La ayuda humanitaria en la Guerra Civil española (1936-1939). Comares Historia, Granada.

Reddy, William M. (2001) The Navigation of Feeling. A Framework for the History of Emotions. Cambridge University Press, Cambridge.

Rodríguez, Mari Carmen (2001) 1936-1939: La Suisse face aux deux Espagnes. Les relations économiques et politiques entre la Suisse et l'Espagne durant la guerre civile espagnole. Mémoire en Histoire contemporaine, Université de Lausanne, not published.
Rodríguez López, Carolina; Ventura Herranz, Daniel (2014) “De exilios y emociones". Cuadernos de Historia Contemporánea, 36: 113-138.

Rosenwein, Barbara (2006) Emotional Communities in the Early Middle Ages. Cornell University Press, Ithaca; London.

Rosenwein, Barbara (2002) "Worrying about Emotions in History". The American Historical Review, 107: 821-845.

Sánchez-Collado Jiménez, Juan Carlos (2015) Los evacuados de la Guerra Civil de la provincia de Toledo (1936 - 1939). Tesis Historia Contemporánea, UNED.

Schmidlin, Antonia (1999) Eine andere Schweiz. Helferinnen, Kriegskinder und humanitäre Politik 1933-1942). Chronos, Zürich.

Schmöller, Natascha (2017) Manifestaciones creativas y plásticas en torno a la ayuda humanitaria suiza en España y en el Sur de Francia (1937 - 1943). Tesis Historia Contemporánea, UNED.

Seidman, Michael (2002) Republic of egos: a social history of the Spanish Civil War. University of Wisconsin Press, Madison.

Serrano Sanguilinda, Inmaculada: Return after violence: emotions and rationality in the aftermath of violent conflict. Tesis de la Universidad Autónoma de Madrid: 2010. https://dialnet.unirioja.es/servlet/tesis?codigo=31001 [accessed /April/2017]

Siemsen, Anna (1924) "Psychologische Voraussetzungen für den Sozialismus". In Der lebendige Marxismus. Festgabe zum 70. Geburtstag von Karl Kautsky, edited by Jenssen, Otto. Thüringer Verlagsgesellschaft, Jena: 383-393.

Siemsen, Anna (1937) Spanisches Bilderbuch. Editions nouvelles internationales, Paris.

Siemsen, Anna (1939) El imperio germano. Peligro de Europa. Ediciones Imán, Buenos Aires.

Siemsen, Anna (1981) Preussen. Die Gefahr Europas. Verlag Klaus Guhl, Berlin.

Siemsen, August (1951) Anna Siemsen. Leben und Werk. Europäische Verlagsgesellschaft, Hamburg; Frankfurt.

Sierra Blas, Verónica (2009) Palabras huérfanas. Los niños y la Guerra Civil. Taurus, Madrid.

Taithe, Bertrand (2006) "Cold Calculation in the Faces of Horrors? Pity, Compassion and the Making of Humanitarian Protocols". In Medicine, Emotion and Disease, 1700-1950 edited by A1berti, Fay Bound. Palgrave Macmillan, Basingstoke: 79-99.

Trinidad Lafuente, Isabel (1999) "La Guerra Civil española ¿una parte de la leyenda negra suiza?”. Historia Contemporánea 19, $355-379$.

Weber, Katharina (2010) Die Rehabilitierung der Spanienfreiwilligen in der Schweiz (1946-2009). Master Graduate Work at the University of Zurich, not published.

Weil, Nicole (2010) «Sozialdemokratin und Organisatorin, Regina Kägi-Fuchsmann». In Vergessene Frauen. Humanitäre Kinderhilfe und offizielle Flüchtlingspolitik 1917-1948 edited by Becker, Helena Kanyar. Schwabe Verlag, Basel: 41-61. 